Harris, Franklin 1.

The action of ultraviolet

light on certain bacteria in relation to specfic absorption by amino acids 
sibary ac

- IRVIIE 
UNIVERSITY OF CALIEORNAA LIBRARY. IRVINE

UNIVERSITY OF CALIFORNIA PUBLICATIONS

IN

PATHOLOGY

Vol. 2, No. 21, pp. 245-250

March 25, 1919

\section{THE ACTION OF ULTRAVIOLET LIGHT ON}

CERTAIN BACTERIA IN RELATION

TO SPECIFIC ABSORPTION

BY AMINO ACIDS

. BY

FRANKLIN I. HARRIS AND HUBBARD S. HOYT

$==$

UNIVERSITY OF CALIFORNIA PRESS

BERKELEY 


\section{ONIVERSITY OF OALIFORNIA PUBLIOATIONS}

Note.-The University of California Publications are offered in exchange for tho publ. cations of learned societies and instltutlons, universities and librarles. Oomplete lists of all the publications of the University will be sent upon request. For cample coples, lists of publications or other information, address the Manager of the University Press, Berkeley, Oalifornia, J. B. A. All matter sent in exchange should be addressed to The Exchange Dopartment, Unirorgity Iubrary, Berkeley, California, U. S. A.

PATHOLOGY.-Frederick P. Gay, Editor. Price per volume $\$ 2.50$. Volume I (pp. 349) completed. Volume II in progress.

Cited as Univ. Calif. Publ. Path.

Vol. 1. 1. On the Qnantitative Separation of the Globulins of Femolytic Seram, with Special Beference to the Carbon Dioxide Group, by Clarence Quinan. Pp. 1-5. July 11, 1903

2. On the Hydrolysis of Protamine, with Especial Reference to the Action of Trypsin, by Alonzo Englebert Taylor. Pp. 7-31. February 17, 1004

3. On the Syuthesis of Fat through the Revereed Action of a Fat-8plitting Enzyme, by Alonzo Engelbert Taylor. Pp. 33-12. March 29, 1904.

4. On the Occurrence of Amido-Aclds in Degenerated THssues, by Alonzo Englebert Taylcr. Pp. 43-47. March 30, 1904.

Nos, 3 and 4 in one cover.

5. On the Autolysis of Protein, by Alonzo Englebert Taylor. Pp. 49-63. June 24, 1904.

6. On the Beversion of Tryptic Digestion, by Alonzo Englebert Taylor. Pp. 65-70. June 24, 1904.

No8, 5 and 6 in one cover

7. Studies on an Aoh-Free Diet, by Alonzo Englebert Taylor. Pp. 71-86. July 30, 1904

8. On Formentation, by Alonzo Englebert Taylor. Pp. 87.341. February 16,1907

9. On the Syathesis of Proteln through the Action of Trypein, by Alonso Englebert Taylor. Pp. 343-347. February 21, 1907

No. 8, On Fermentation, is also published eeparately, in a brochuro of 255 pages. Price $\$ 2$.

Vol. 2. 1. The Fixation Reaction in Relation to the Formation of Specific Serum Procipitates, by Frederick P. Gay. - Pp. 1-22. August 22, 1911.

2. A Comparison botween the Bordet-Gengon Fixation Reaction and the Wassermarn Reaction, based on the Relative Dosage of the Reacting Substances, by Frederick P. Gay. Pp. 23-28. Auguat 22, 1911 ........

3. On the Relation between Rat and Iuman Leprosy, by I. S. Schmitt. Pp. 29-37. September 2, 1911

4. The Non-Antigenic Properties of Lipolds Extracted from Human Livers with a Method of Preparation of Antigen for Use in the Wassermann Reaction, by J. G. Fitzgerald and J. B. Leathes. Pp. 39-46. May 17, 1912

5. Syetemic Oldiomycosis, a Study of Two Cases Developing Terininal Oidiomycetic Meningitis, by Glanville $\mathbb{Y}$. Busk. Pp. 47-58. June 21,1912

6. Studies on the Origin of Antibodies I. The Persistence of a Soluble Antigen in the Sornm of Immunized Rabbits, by Frederick P. Gay and G. Y. Rusk. Pp. 59-72. June 21, 1912.

7. Note on the Negative Effect of Iodipin on the Output of Artificial Hemolysins, by Frederick P. Gay and G. Y. Rusk. Pp. 73-76. Juno 21, 1912.

Nos. 6 and 7 in one cover

8. An Improved Rapld Method of Producing Precipitins and Hemolysins, by Frederick P. Gay and J. G. Fitzgerald. PD. 77-82. June 26, 1912

9. A Compariscn of Chemical with Microchemical Methods for the Determination of Varying Amounts of Glycogen in the Liver, by G. $\mathbf{Y}$. Rugk. Pp. 83-89. October 31, 1912

10. A Rapld Method of Producing Bacterlal Agglutinins, by Edna Locke. Pp. 91-96. October 31, 1912 


\section{THE AC'TLON OF UL'RATIOLET LIGH'T ON CERTAIN BACTERIA IN RELATION TO SPECIFIO ABSORPTION BY AMINO ACIDS}

BY

FRANKLIN 1. HARRIS AND HUBBARD S. HOYT

(From the Department of Parhology and Bacteriology, University of California)

Within recent years considerable interest has been shown in the study of the ultraviolet radiations in relation to their toxicity for living protoplasm. It was early found that these radiations exert a highly toxic influence on protoplasm exposed to them. Ienri, ${ }^{,}$" in conjunction with rarious co-workers, has done pioneer work in this fiekl, and was the first worker to point ont the possibility of a practical application of this subject, namely, in the sterilization of various sulustances and solutions. Further work on the germicidal effect of nltraviolet light has been done hy Houghton and Davis, ${ }^{3}$ who fomd that the rays produced by the Cooper-Hewitt mereury are exert a strong bacturial artion on various species of bacteria, including spore forming or can nisms.

The action of these radiations was recognized as a photochemical provess, and was supposed to he due to the absolption of the rays by the barterial protoplasm. In a previous reports. we studical this plase of the problem and proceeded on the basis of the first law of photochemical action, that in a photochemical system, to he effective, the rays must he absurbed. usually by speeific ronstituents. We have further shown that the toxie 
action of ultraviolet light ubeys this law and is clue to the absorption of the rays by eertain eonstituents of all living protoplasm. namely, the tyrusine and phentalanin radicals of the protein mokerules. These two aridis are the specifie absortents in living protoplasm for the rays of the meremry are.

The object of the present work was to confirm this work, using bacteria as a biolngical test. and further to study the retative speed of absorption of the ultraviolet rays by the protoplasm of the varions types of bacteria.

\section{METHODS}

Three organisms were selected as typifying three general groups of bacteria, which are classerl on the basis of the possession or lack of protective structures, spores and capsules.

1. A non-sporulating. non-eapsulated organism, staphylococeus aureus.

2. A sporulating. non-capsulated organism, Bacillus subtilis.

3. A capsulated, non-spormlating organism, IS. mucosus capsulatus.

For the exposure of these oranisms valions methods were tried. The organisms were glown on agar slants for twenty-four lumes, and then washed off with sterile $0.85 \%$ NaCl. I prelininary exposure was made with a given amount of each saline sispension exposed directly to the rays. As no eonsistent results Wepe obtained by this method, due uidembtedly to the absorption of the rays by the upper layers of the bacterial suspension, this methoul was abandoned.

A number of plating methorls wee then tried. Metted angal was poured at $42^{\circ}$ ( $^{\prime}$ and allowed to harden in ten centimeter potri dishes. To prevent condensation it was found best to cover with sterite tile covers. After hardening three methods of inoculation were trixd.

a. 'Two separate streaks were made with a boup full of salline suspension, one on cither sile of the diameter of the plate. Iralf of the plate was then exposed, the other half being protected by a ghass rovere, coromed with black paper. 'The plate was then 
innolated twenty-fome lours, and the rolonios were identified diresetly, or, in suspiejons cases, smears were madre. The ohjection to this method was that there was no reotainty that the ronf wol streak and the exposed streak were similarly inoeulaterl.

b. To overeome this objowtion a singlo latge streak in thr shap' of the letter" "Y" was made of onc loopful of bacterial suspension, and half the plate cxposed als lonfore

(. Amother plating methoul experimented with wats to flowel the mintio plate with a definite anoment of saline smspension and them axponse one side, as in the? above.

l'Jating methods were also abandoned finally becans: they did not yirlol miform lesults, due mudnubtedly to some organismis gretting in under the agar and being protected loy tho protein material.

The method finally employed was a cover slip method suggested by Professor Ivan C. Hall. Upon one surface of a sterile cover slip one loopful of saline suspension of a twenty-fonr hour agar growth was placed and allowed to dry in a sterile potris dish. Assuming the saline suspension to be uniform each cover slip therefore had approximately the same number of organisms. When dry the corer slips wore exposed directly to the rays by placing them in a petri dish $12 \mathrm{~cm}$. below the are of the CooperHewitt machine. After the wiven exposure the cover slip was picked up with sterile forceps, dropped into a tulbe of broth, the hroth was incubated for forty-eight hours, and the results observed. The growth of these thre organisms in broth is quitr characteristic, and no further examination was usually necessary. In dombtful cases agar plates were streaked from the loroth and the organisms were identified ly the usual methods.

The axposures varied from five secunds to 200 seeonds. Somewhat over 100 exposures were made, and although there were slight discrepancies in the results, due to the objeetims mentiomed to plating methods, consistent results were obtained by the coyre slip method, so that we may definitely say that:

Bacillus mucosus capsulatus was killed after 20 secumals.

staphylococeus " " " " "

b. subtilis " " " $" 150$ " 
These figures represent the mative resistance of these thros organisms.

'the protective action of the amino acids was then studied. The rover" slips wre exposed as before, but between the cover slip and the are a quartz bealker containing the given amino acid was interposed, so that the rays beture striking the ormanisms passer through the amino aciuls. The results ubtained confirm our previous work. With $B$. sublitis, whose normal extermination perint is 150 seconds, we found exposure for forty mimutes to ultraviolet light passed through $1 \%$ tyrosin solution exerted no toxic effect upon the bacilli, a good growth being obtained in forty-eight hours. Similarly. Staphylococcus aurcus gave good growth after forty minutes; b. mucosus capsulatus, though not tested after longer axposure, gave satisfactory growth after ten minutes.

A good growtl was also oltained with amino-benzoic arid after exposure of these organisms for 3200 seconds to ultrariolet light detoxicated by passing throngh this substance. Phenylalanin rould not be secured, but there is little doult that similar results could be ohtained with it.

These results confirm thuse of our previons reportt.5 and indicate that the aromatic amino-acid radicals are the absorbing sulustances in bacteria as well as in jrotozoa. Kober's work placerl the ahsorption hand for tyrosin at 248 to $297 \mu$, or $2480-$ 2970 Angstrom units, of wave length, and for phenylalanin 236$271 \mu$ or $2360-2710$ Angstrom units.

Therefore ultraviolet light, of wave lengths $2360-2970 \mathrm{Ang}-$ strom mits. should eontain practically all of the rays toxie for protoplasm. Two recent papers bave appeared, however, which report different results. Browning and Russ' found the toxie action of ultraviolet light falling oft shapply at $2960 \mathrm{~A} .1$.. which would apparently "orrespond with one edge of the tyrosine bant. They report, lowerer. an apparently constant toxieity from

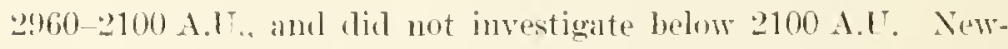
comer. a reporterl also a comstant toxicity from $2100 \mathrm{~A} . \mathrm{l}$. 11p to a little less than 2900 A.U., the toxicity falling off to practieally

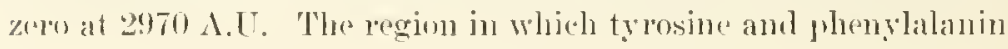


are both absorthed, i.e. 2480 to 2710 A.U., should be the most toxie for protoplasm, whereas the region containing walve lengths shorter than $2300 \mathrm{~A}$.U. should be relatively nou-toxic.

Our former exporiments eonehsively demonstrated that a solution of toresine will absorb pratetieally all of the toxice ralys. those getting through not being sufficiently toxic to kill paranecia after exposure tor forty mimutes, whereas il the rays ahsomber by tyrosine were allowed to anot the paramecia were killed in 100 secends.

\section{Concluesons}

1. The aromatic amino areid rarlicals are among the sulbstanees in hacteria affected ly the action of ultraviolet light, as was shown for paramecium in a previous report.

2. The ultraviolet ratiations produced by the merury are of wave lengths not absorberl by trososine and phenylabunin are relatively non-toxic. 'Pluerefore, nsing Kober's determinations for the wave lengths corresponding to these two absorption bands, the ultraviolet radiations which are toxic for protoplasm are of wave lengths from $2480-2710$ A.U.

3. In the three types of bacteria studied capsulated organisms were found to be most suseptible and sporulating organisms most resistant to the action of nltraviolet light. The work snggests strongh that the protoplasm of Bacillus mucosus capsulalus contains greater amounts of the above mentioned substances than the non-capsulated staphylocoecus and the sportulating hay bacillus. 


\section{LITERATURE (TTED}

I Ienri, Yictor, Ilelloronner, André, and de Recklinghausen, Max. Stérilisation de grandes quantités d 'eau par les rayons ultraviolets. Compt. rend. de l'Acat. d. Sci., T. 150, 1910, 1'1. \$132-934.

2 Bielecki, Jean, and Henri, Victor. Etude quantitative de l'absorption des rayons ultraviolets jar les cétones, les dicétones et les acides cétouiques. Compt. rend. de I'Acad. d. Sci., T. 156, 1913, pp. 1322-1324.

3 Houghton, E. N., and Davis, Lewis. A Study of the Germicidal Aetion of the Ultraviolet Rays. Am. Jour. of l'ublic llealth, vol, iv, 1914, 10. 224-240, 3 text figs.

4, 5 Harris, F. I., and Joyt, H. S. The Possible Origin of the Toxicity of Ultra-violet Light. Srience, n.s., vol. xlvi, 1917, p1. 318-320. Rieview in The Jour. of the Am. Mer. Assoe., vol. lxix, 1917, pp. 1433-1434.

6 Kober, I. A. Speetrographie Study of Amino Acids and Folypeptides. Jour. Biol. Chem., vol. xxii, 1915, pl. $433-141$.

$\checkmark$ Browning, C. H., and Russ, Sichey. The Germicilal Action of UltraTiolet Rariation, and its Correlation with Selective Absorption. Proc. of the Rov. Noc., Ser. B., vol. $90,1917, \mathrm{pp}, 33-38, \mathrm{pl} .3$.

8 Newconer, H. S. Baetericidal Fluoreseence Excited by X-rays. Jour. Exp. Med., vol. xxvi, 1917, pr. 65i-668

- Abiotic Action of Ultra-violet Light. Jour. Exp. Med., vol, xxvi. pl. $841-8+5$, pl. 66. 
$$
\text { . }
$$ 



\section{UNIVEESITY OF OALIFORNIA PUBLIOATIONS-(Oontinued)}

11. A Stable Medlum for the Production of Potent Tetanus Torio, by Ivan C. Hall. Pp. 97-102. Angust 30, 1913

12. The Impossibility of Differentiation Between Monkey Blood and Human Blood by Means of Antlsera Dorived from Monkeys, bJ Hugh $\mathrm{K}$. Berkeley. Pp. 105-110. September, 1913

13. Studies on Oonglutination, by Iran C. Fall. Pp. 111-125. September, 1913

14. Preliminary Note on a Skin Reaction Indicating Protection Against Typhoid Fever, by F. P.-Gay and J. N. Force. Pp. 127-130. November, 1913

15. Forensic Value of the Precipitin Test in the Enforcement of the Game Laws in California, by Frank C. Clarke. Pp. 131-138. April, 1914....

16. Studies on the Iocus of Antibody Formation II. The Effect of Benzol Intoxication and Consequent Ireucopenia on the Formation of Artificial Hemolysins and Precipitins, by G. Y. Rusk. Pp. 139-145. Septernber 1914

17. A New Aerobic-Anaerobic Culture Tube, by Ivan C. Hall. Pp. 147-155. Septenlber, 1915

18. Studies on the Formation and Antigenic Propertics of Certain Compound Proteins, by Carl L. A. Schmidt. Pp. 157-204. August, 1916

19. An Investigation of the Ratio of Glolulins to Albumins in the BloodSerum of Normal Rabbits and of Rabbits Immunized Against Bacillus Typhosus, by Homer Righett1. Pp. 205-214. September, 1916 ..

20. The Effect of Certain Aluminum Compounds on the Metabolisu of Man, by Carl I. A. Schunidt and D. R. Hoagland. Pp. 215-244. March, 1919

21. The Action of Ultraviolet Iight ou Certain Bacteria in Relation to Specific Absorption by Amino Acids, by Franklin I. Harris and Hubbard S. Hoyt. Fp. 215-250. March, 1919

PHYSIOLOGY.-S. S. Maxwell, Editor. Price per volume \$2. Volumes I (pp. 217), II (pp. 215), III (pp. 197), and IV (pp. 228) completed. Volume V in progress.

Vol. 4. 1. Experiments on the Functions of the Internal Ear, by $\mathbf{S}$. S. Maswell. Pp. 1-4. September, 1910

2. On the Rise of Temperature in Rabbits, caused by the Infection of Salt Solutions, by Theo. C. Bumett. Pp. 5-7. September, 1910 .

3. A Biochemical Conception of Dominance; by A. B. Moore. Pp. 9-15. September, 1910

4. Galvanotropic Orientation in Gonium Pectorale, by A. B. Moore and T. H. Goodspeed. Pp. 17-23. May, 1911

5. On a Possible Source of the Biological Individuality of the Tissues and Tissue-fluids of Animal Species, by T. Brailsford Robertson. Pp. 25-30. May, 1911

6. Some Factors Influencing the Quantitative Determination of Gliadin, by J. F. Greaves. Pp. 31-74. August, 1911

7. Errors in Refraction Occurring in the Students of the University of California, by Theo. C. Burnett. Pp. 75-77. August, 1911

8. On the Oytolitic Action of Ox-Blood Serum upon Seq-urchin Fggs, and Its Inhibition by Proteins, by T. Brailsford Robertson. Pp. 79-88. Fobruary, 1912

9. On the Nature of the Cortical Layer in Sea-urchin Eggs, by A. R. Moore. Pp. 89-90.

10. On the Nature of the Sensitization of Sea-urchin Eggs by Strontium Chloride, by A. R. Moore. Pp. 91-93.

Nog. 9 and 10 in one cover. March, 1912

11. On the Isolation of Oäcytage, the Fertilizing and Cytolyzing Substance in Mammalian Blood Sera, by T. Brailsford Robertson. Pp. 95-102.

12. On the Fxtraction of a Substance from the Sperm of the Sea-urchin (Strongylocentrotus purpuratus) which will Fertilize the Fggs of that Specles, by T. Brailsford Robertson. Pp. 103-105.

13. The Demonstration of "Masked" Iron in Blood, by C. B. Bennett. Pp. 107-108.

Nos. 11, 12, and 13 in one cover. March, 1912 
18. On the Volume Changes in the Arsu turswo cular Exercise, by Esther $\nabla$. Starkweather. Pp. 187-200. October, 1913

19. The Blood-pressure Effects of the Application of Creatin to the Cerebral Cortex, by R. S. Sherman. Pp. 201-206, plate 1. September, 1914

20. A Comparison of the Weights at Birth of British Infants Born in the British Isles, the United States, and Australia (Preliminary Communication), by T. Brailsford Robertson. Pp. 207-210. January, 1915

21. Tables for the Computation of Curves of Autocatalysis, with Especial Reference to Curves of Growth, by T. Brailsford Robertson. Pp. 211228. March, 1915

Vol. 5. 1. The Effect of Lecithin and Cholesterol upon the Division Rate of Paramecium, by Aline Browder. Pp. 1-3. September, 1915

2. The Simultaneons Administration of Pituitary and Thymus to Growing Chicks, by Samuel S. Maxwell. Pp. 5-8. March, 1916

3. The Growth of Normal and Hypophysectomized Tadpoles as Influenced by Endocrine Diets, by P. E. Sinith. Pp. 11-22, 2 figures in text. April, 1918

4. Table of $\mathrm{PF}, \mathrm{H}^{+}$and $\mathrm{OH}^{-}$Values Corresponding to Electromotive Forces Determined in Hydrogen Electrode Measurements, with a Bibliography, by Carl L. A. Schmidt and D. R. Hoagland. Pp. 23-68.... (In press)

\section{MEMOIRS OF THE UNIVERSITY OF CALIFORNIA (Quarto).}

VoI. 1. 1. Triassic Ichthyosauria, with special reference to the American Forms, by John C. Merriam. Pp. 1-196, plates 1-18, 154 text figures. September, 1903

2. The Fauna of Rancho La Brea. Part 1, Occurrence, by John C. Merriam. Pp. 197-213, plates 19-23. November, 1911

The Fauna of Rancho La Brea. Part 2, Canidae, by John C. Merriam. Pp. 215-272, plates 24-28, 35 text figures. October, 1912

Vol. 2. The Silva of California, by Willis Linn Jepson. 480 pages, 85 plates, 3

maps. December, 1910. Cloth $\$ 7.50$, paper .............................................

Vol. 3. Business Cjcles, by Wesley C. Mitchell. xviii +610 pages, with 77 charts. September, 1913. Cloth, \$7.50, paper

Vol. 4. 1. The Battle of the Seven Arts; a French Poem by Fenri d'Andeli, Trouvère of the Thirteenth Century. Edited and Translated, with Introduction and Notes, by Louls J. Paetow. July, 1914

Other series in Agricultural Selences, American Archaeology and Ethmology, Botany, Classical Philology, Economics, Education, Egyptian Archaeclogy, Eugineering, Entomology, Geography, Geology, Graeco-Roman Archaeology, History, Mathematics, Modern Philology, Psychology, Semitlc Philology, Zoology.

UNIVERSITY OF CALIFORNIA CHRONICLE.-An official record of University llfo, Issued quarterly, edited by a committee of the faculty. Price $\$ 1.00$ per year. Current volume No. XXI.

ADMTNISTRATIVE BULIETINS OF THE UNIVERSITY OF CALIFORNIA.-Edited by the Recorder of the Faculties. Includes the Register, the Prosident's Report, the Secretary's Report, and other official announcements.

Address all orders or requests for information concerning the above publication to the University of Callfornia Press, Borkeley, Callfornia. 


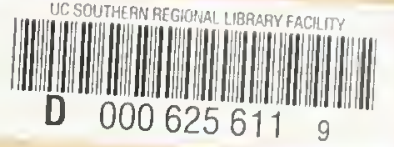


